\title{
Improving Role of Construction Industry for More Effective Post- Disaster Emergency Response To Road Infrastructure in Indonesia
}

\author{
Krishna S. Pribadi ${ }^{1, *}$, Eliza Puri ${ }^{1}$, Eliya Hanafi ${ }^{1}$, and Tri Hadinata ${ }^{1}$ \\ ${ }^{1}$ FTSL Institut Teknologi Bandung, Department of Civil Engineering, Jl. Ganesha 10 Bandung 40181, Indonesia
}

\begin{abstract}
Geo- and hydro-meteorological disasters typically caused disruptive impact to road networks due to damaged road infrastructure, which in turn disconnect access to and isolate the disaster affected areas. Road clearing work and emergency road recovery operation are considered a priority to reconnect the access during post-disaster emergency response. However, the operation is not always smooth and in many cases delayed due to various problems. An investigation is conducted to understand the current practice of post-disaster emergency road recovery operation in Indonesia and to study possible participation of construction industry in order to improve its effectiveness. In-depth interviews with Local Disaster Management Agencies (BPBDs) and local road agencies in West Java Province were conducted to understand current practices in emergency road recovery operation and to view perspectives on local contractor participation. The surveys showed supports from the local governments for contractor involvement as long as it is still under guidance of related agencies (Ministry of Public Works and Housing) despite some possible obstacles from the current regulation that may hamper contractors' participation, which indicate that there is a potential role of construction industry for more effective post-disaster emergency response, provided that contractor associations are involved and existing procurement regulation is improved.
\end{abstract}

\section{Introduction}

Indonesia is vulnerable to many different types of hazards. According to National Disaster Management Agency (BNPB), there are at least 20 categories of natural and man made hazard in Indonesia. Related to road networks, landslide is an important secondary hazard in Indonesia and is closely associated with flooding, earthquake, and volcanic activity (CFEDMDA, 2015). These hazards have been known for the disruptive effect to the road service due to damages and debris caused by the impact of the hazards, and in some cases causes disruption of access to the disaster affected locations.

Transport/access road disruption into and out of the affected area have been considered as a vital constraint in providing efficient response in disaster and post disaster reconstruction activity [1]. Not only does a functioning access road may save lives through enabling access for evacuations, but also help a speedy distribution of goods and helps into the affected area [2]. Thus functioning road networks or access road have been proven to have a major and important role [2]. However, some cases have shown that fast and propre emergency response to recover road functions was often delayed by several factors, such as lack of heavy equipment and skilled operators, unavailability of standby emergency fund, and delayed response decisions due to regulation constraints. The pre-arranged participation of private sector or construction industry may be considered as a solution to improve the process, as [3] suggested that construction companies already in the affected areas may contribute better labour, materials and equipments supported by good networks and supply chain for immediate relief which also include debris removal and emergency repair to put back the road function.

This paper tries to identify factors including scheme and obstacles during emergency response and provide recommendation on how to improve construction industry participation as a solution for an effective and timely post-disaster emergency response.

\section{Post Disaster Emergency Response Mechanism in Indonesia}

\subsection{Role Sharing and Coordination}

The Law No. 24/2007 concerning Disaster Management was enacted in 2007 and the National Disaster Management Agency or Badan Nasional Penanggulangan Bencana (BNPB) was established in

\footnotetext{
* Corresponding author: kspribadi@gmail.com ; ksuryanto@si.itb.ac.id
} 
2008. As the national agency, BNPB is responsible to coordinate and implement disaster management activities at the national level, while at the local level, Local Disaster Management Agencies or Badan Penanggulangan Bencana Daerah (BPBDs) are established in the provinces, cities and regencies, with the similar responsibilities with BNPB at their own jurisdictions. Fig. 1 shows the coordination mechanism between different organizations and agencies for disaster management. The Law 24/2007 establishes three stages of disaster management, i.e. pre-disaster, emergency response, and post-disaster. This study focus on the emergency response stage. During this stage, rapid and immediate respond is needed to prevent further victim and infrastructure losses. Activities in this stage consist of rapid assessment of location affected by the disaster, damage and losses, and needed resources, decide on disaster emergency status, rescue and evacuation of disaster affected community, provision of basic necessities, protect vulnerable groups and immediate recovery of essential facilities and infrastructure.

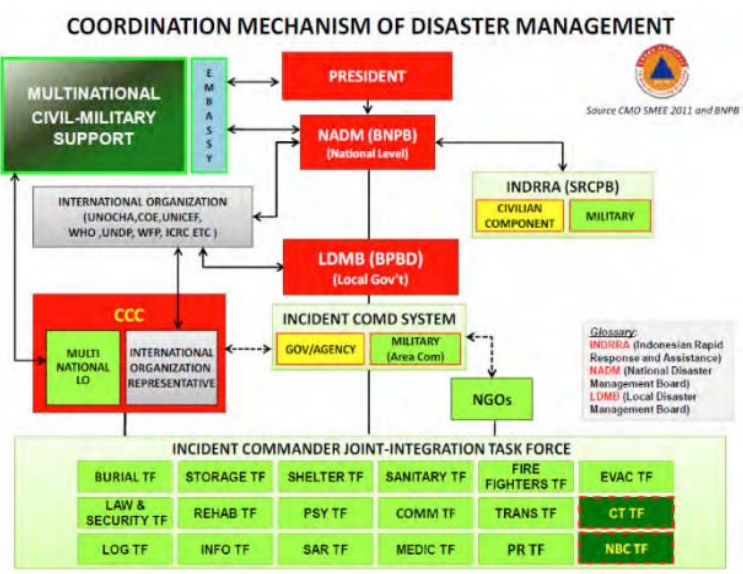

Fig. 1. Coordination Mechanism of Disaster Management (Source: [4] ).

Immediatelly after a disaster strikes and is reported, Rapid Response and Assistance Team from Local Disaster Management Agency (BPBD) will be dispatched to conduct rapid assessment related to the disaster. Their report and recomendation will be collected and submitted to Governor or Regent/Mayor as a basis for declaring disaster emergency status. Next, all local agencies representatives will join the Rapid Response and Assistance Team (Tim Reaksi Cepat) dispatched by the local BPBD to the impacted area. They will coordinate with BPBD on the issues of rescues, evacuation and delivery of basic needs aid.

In particular, related to emergency restoration of road access, the agency responsible for the operation is the road administration agency, depending on the level of the road hierarchy, e.g. for the national road the authority is the Directorate General of Road Development under the Ministry of Public Works and Housing (DGRD$\mathrm{MoPWH}$ ), for the provincial roads, the authority is under the Provincial Public Works Agency and in some cases the Provincial Road Agency, depending on the provincial government structure. For the City/Regency Road, the authority is under the Public Works or Road Agency of the municipality/regency. These agencies are in close coordination with the Local Disaster Management Agency (BPBD) for conducting fast response related to road and other infrastructure recovery in the post-disaster emergency situation. In the postdisaster emergency response, emergency access road restoration should be conducted rapidly to support other activities (rescues, evacuation, aid distribution). While to reconnect the disconnected access, road clearing is usually the first task for the post-disaster process [5].

\subsection{Post-Disaster Emergency Funding}

Disaster management fund sources and fund use, financing, supervising, reporting and accountability guidelines are provided in Presidential Regulation No.22/2008 concerning Disaster Aid Financing and Management. In the implementation, the state budget (APBN), the local budget (APBD) and social/community funding are stipulated as the main fund sources. However, during disaster emergency response, fund source may also utilize work unit budget, and in this case of road clearing and temporary repair, national or local Road Authority or Public Works Department (PWD) unit. The provision of on-call budget for emergency response is regulated in the Head of BNPB Regulation (PERKA) No.6A/2011 concerning Emergency Fund Guideline. Basically the Regulation divides emergency response situation into three statuses, i.e. emergency alert, emergency response and emergency transition to recovery. Activities related to debris removal and emergency temporary repair of road infrastructure in order that the road can be functioned again in the emergency situation are considered as in the emergency response status within the emergency relief category. Table 1 explains the use of the on-call funding.

Table. 1. Use of on-call budget for road clearing and repair (Source : PerkaBNPB6A/2011 concerning emergency fund guideline)

\begin{tabular}{|l|l|l|}
\hline $\begin{array}{c}\text { Emergency } \\
\text { Status }\end{array}$ & Activity & \multicolumn{1}{c|}{ Use of on-call fund } \\
\hline $\begin{array}{l}\text { Emergency } \\
\text { response } \\
\text { status }\end{array}$ & $\begin{array}{l}\text { Emergency } \\
\text { relief }\end{array}$ & $\begin{array}{l}\text { Procurement of good and } \\
\text { services required to clear } \\
\text { debris and landslide, repair } \\
\text { of dikes, repair/build } \\
\text { emergency road/bridge/ } \\
\text { quay and other relevant } \\
\text { equipment/plant } \\
\text { (Clause II.B.2.b.2) }\end{array}$ \\
\hline
\end{tabular}

The Minister of Home Affaires (MoHA) regulation No.13/2006 about guidance for local government allocation states that Government can use Unexpected Expense Fund or Belanja Tidak Terduga (BTT) during post-disaster emergency response to prevent further damage and social distructive effect, based on the Mayor/Head of Local Government statement of disaster 
emergency situation. In emergency situation, BTT can be used and the expenses and/or reimbursement should be reported. The treasurer of the office/agency in charge will be responsible for the reporting. The decision of the Mayor/Head of Local Government to declare emergency statement should be based on the recommendation of the relevant agency (BPBD). Most of the local governments have their on local regulation stipulating the procedure and responsibility of using BTT for emergency response.

A typical procedure for using BTT from a local government usually requires the following documents:

- A rapid and proper assessment to identify location, victims, damage and loss of infrastructure

- Declaration of disaster emergency status by the Head of Local Government

- A brief action plan stating activities during the emergency response with the detailed allocation and expense.

Based on the above documents, the Head of Local Government will issue the permit to use BTT fund stating the amount of BTT fund. More detailed procedures are usually stated in the SOPs of each local government.

\section{Common Practices in Other Countries}

It is very common to have agreements between local government and business companies or private sector in Japan, which may concern electricity recovery, medication, logistics and foods companies. Support of the private sector includes companies in the construction, transportation, and retail sectors. They played a key role in the response as they brought in expertise and assets that benefited the response, although in some cases it was improvised and unanticipated, as suggested by Taniguchi et al. in [5].

Contractors in Japan enter into agreement with local governments to do some road clearing without waiting for the instruction in case a natural disaster occurs. The scheme of the framework agreement in Japanese is called 'Kyoutei'. This practice is very useful to speed up the response action to put back the affected roads in operation [6]

In general, if an emergency process is used for selecting a contractor, it is still important that proper procurement procedure be followed and that the afore mentioned considerations in establishing a pre-disaster plan be applied [7]. Specifically for debris removal, it was suggested that bids and/or quotes from contractors should contain the following information:

1. The approximate quantity of debris

2. The specific disposal location

3. The unit price per cubic yard or ton

4. Mobilization time and cost

5. References and proof of insurance

\section{Post Disaster Emergency Response Works in Indonesia}

\subsection{Civil Works in Post Disaster Emergency Response}

To prevent further damage and losses to the affected areas caused by delayed response operation as well as to prevent work accident, road clearing and emergency repair works should be conducted by professional personnel, which may include local experienced contractors with adequate resources. However, in actuality, there are cases where the locals with lack of skill and knowledge are participating in emergency operation, such as in Banyumas Regency landslide in February 2017 [8] where road clearing operation was under the command of Banyumas BPBD, involving military personnel and volunteers from local community with no special skill on debris removal under hazardous situation.

Civil works recovery on disaster affected areas, which include road clearing, debris removal and temporary road structure works are needed to put back the function of the road infrastructure, either temporarily or permanently. The works may require the mobilization of heavy equipment for earthwork, such as dozers, excavators, shovel, and compactors, to rapidly recover the access. Hazardous site condition and constraints on logistics as well as pressure to reopen the road back to traffic as soon as possible will increase the complexity of the work on site, thus competent field engineers and supervisors, skilled operators and workers are needed for optimum results.

\subsection{Contractor Involvement During Post Disaster Emergency Response}

Road clearing and emergency access road recovery become critical activities when disaster impacts road which serve as the only access to deliver logistics to the affected areas. Since road clearing and emergency access road recovery are in the critical path of post-disaster emergency response activities, the construction industry is well placed to participate in and contribute to the process. Another benefit of involving construction industry or private sector is that when they prepare their own Business Continuity Plan (BCP), they can take advantage of their involvement in the emergency operation by supporting a wider region contingency and survival-ability plan enabling resource mobilization from private for the public [5], which in turn will help in the quick recovery of businesses in the disaster affected region. In addition, the participation of local contractors in the recovery process will also help the local economy recovery, by providing livelihood to the local people and by promoting the local economic activity through the provision of good and services in the region, thus providing opportunity for local suppliers (materials and equipment) to be engaged again in activity.

In accordance with Presidential Regulation No.70/2012 on Procurement of Goods and Services for 
Government, the private sector can be directly appointed by local agency considering the need of immediate works to prevent further losses caused by the disaster. The experience of the local contractor can become an added value to complete the task immediately and reliably. The presence of a local contractor will cut the local agencies coordination, and make the road clearing task more efficient.

\subsection{Views of Local Government Agencies Related to Contractor Involvement During Post Disaster Emergency Response}

During this research, several interviews had been conducted with local agencies related to contractor involvement during post-disaster emergency phase. The local agencies such as military and police organization (TNI/Polri), transportation agency, Indonesian Red Cross and Social agency are not included in this research since the research is more concerned with Local Disaster Management Agency (BPBD) and Road Agency or Public Works Department (PWD) as the main actors in the reopening of impacted road and bridges and they are considered as having better understanding on the technical operation. Table 2 and Table 3 show the result of all local agency perspective about contractor involvement.

Four local agencies seem to agree with the idea of contractor involvement. They consider that the works would be much easier to be conducted. The procurement process would be under PWD because of their mandate and the technical expertise.

Table 2. Interview Response Related to Contractor Involvement and Procurement

\begin{tabular}{|c|c|c|}
\hline $\begin{array}{c}\text { Local } \\
\text { Agencies }\end{array}$ & $\begin{array}{c}\text { Response related } \\
\text { to contractor } \\
\text { involvement }\end{array}$ & Procurement Process \\
\hline $\begin{array}{c}\text { BPBD of } \\
\text { Bandung } \\
\text { District }\end{array}$ & $\begin{array}{l}\text { Does not agree } \\
\text { with contractor } \\
\text { involvement }\end{array}$ & $\begin{array}{l}\text { Response managed by } \\
\text { PWD of } \\
\text { Province/district }\end{array}$ \\
\hline $\begin{array}{c}\text { BPBD of } \\
\text { Sumedang } \\
\text { District }\end{array}$ & $\begin{array}{l}\text { Agree with } \\
\text { contractor } \\
\text { involvement }\end{array}$ & $\begin{array}{l}\text { Managed by PWD } \\
\text { Province/district }\end{array}$ \\
\hline $\begin{array}{l}\text { BPBD of } \\
\text { West Java } \\
\text { Province }\end{array}$ & $\begin{array}{l}\text { Agree with } \\
\text { contractor } \\
\text { involvement }\end{array}$ & $\begin{array}{l}\text { Managed by PWD } \\
\text { Prov/district }\end{array}$ \\
\hline $\begin{array}{c}\text { PWD of } \\
\text { Bandung } \\
\text { District }\end{array}$ & $\begin{array}{l}\text { Agree with } \\
\text { contractor } \\
\text { involvement }\end{array}$ & Direct Appointment \\
\hline $\begin{array}{l}\text { Bina Marga } \\
\text { West Java } \\
\text { Province }\end{array}$ & $\begin{array}{l}\text { Agree with } \\
\text { contractor } \\
\text { involvement with } \\
\text { amendment of } \\
\text { regulation } \\
\text { especially for } \\
\text { procurement } \\
\text { process }\end{array}$ & $\begin{array}{l}\text { - Direct Appointment } \\
\text { - Tendering method can } \\
\text { not be implemented as } \\
\text { it will take time and can } \\
\text { not follow the } \\
\text { procedure stipulated in } \\
\text { Pre.Reg No 70/2012 }\end{array}$ \\
\hline
\end{tabular}

Table 3. Interview Response Related to Funding Source and Obstacle

\begin{tabular}{|c|c|c|}
\hline $\begin{array}{c}\text { Local } \\
\text { agencies }\end{array}$ & $\begin{array}{c}\text { Source of } \\
\text { Post-Disaster } \\
\text { Emergency Fund }\end{array}$ & Perceived Obstacles \\
\hline $\begin{array}{c}\text { BPBD } \\
\text { Bandung } \\
\text { District }\end{array}$ & $\begin{array}{l}\text { Emergency/On-call } \\
\text { Fund (Dana Siap } \\
\text { Pakai/DSP) }\end{array}$ & $\begin{array}{l}\text { Non trustable } \\
\text { Contractor, will be } \\
\text { difficult to manage }\end{array}$ \\
\hline $\begin{array}{l}\text { BPBD } \\
\text { Sumedang } \\
\text { District }\end{array}$ & $\begin{array}{l}\text { Emergency/On-call } \\
\text { Fund (Dana Siap } \\
\text { Pakai/DSP) }\end{array}$ & $\begin{array}{l}\text { Lack of experience to } \\
\text { respond to disaster in } \\
\text { Sumedang Area. } \\
\text { BPBD Sumedang } \\
\text { District was } \\
\text { established in } 2015\end{array}$ \\
\hline $\begin{array}{l}\text { BPBD } \\
\text { West Java } \\
\text { Province }\end{array}$ & $\begin{array}{l}\text { Emergency/On-call } \\
\text { Fund (Dana Siap } \\
\text { Pakai/DSP) }\end{array}$ & $\begin{array}{l}\text { BPBD doesn't have } \\
\text { supporting facility } \\
\text { like the presence of } \\
\text { technical experts }\end{array}$ \\
\hline $\begin{array}{l}\text { PWD } \\
\text { Bandung } \\
\text { District }\end{array}$ & $\begin{array}{l}\text { Bina Marga's } \\
\text { Maintenance } \\
\text { Allocation first, then } \\
\text { request } \\
\text { reimbursement using } \\
\text { Emergency/On-call } \\
\text { Fund (Dana Siap } \\
\text { Pakai) to BPBD's }\end{array}$ & $\begin{array}{l}\text {-The lack of } \\
\text { availability of heavy } \\
\text { equipment on disaster } \\
\text { site } \\
\text {-The availability of } \\
\text { Emergency Fund }\end{array}$ \\
\hline
\end{tabular}

\subsection{Constraints to Road Clearing and Temporary Repair Operation in Post-disaster Emergency Response}

\subsubsection{Availability of Heavy Equipment in Local Government}

Delays in the emergency road clearing and repair operation have been experienced in many post-disaster cases, due to the unavailability of adequate heavy equipment in the vicinity of the affected roads. Fig.2 shows the unbalanced distribution of heavy equipment registered at the $\mathrm{MoPWH}$, belonging to various construction and heavy equipment firms as well as to various MoPWH local offices. The figure was based on an equipment register database maintained by $\mathrm{MoPWH}$, which is far from being complete, totalling only about 4800 units. The equipment relevant to road clearing and temporary repair are about $50 \%$ of the registered equipment. Actually, there are more heavy equipment available belonging to other organizations/agencies, such as mining companies, military engineering divisions, aggregates and asphalt/cement mix producers, etc. The figure indicates that provinces with high vulnerability are not always equipped with sufficient number of heavy equipment, while DKI Jakarta (the capital) with low landslide hazard is well equipped.

\subsubsection{Lack of Skilled Human Resources}

During post-disaster emergency operations, the availability of suitably skilled labour may be limited due to a combination of small local capacities and high demand [9]. Those are also experienced in Indonesia, as an interview with one of local PWD officers shows that 


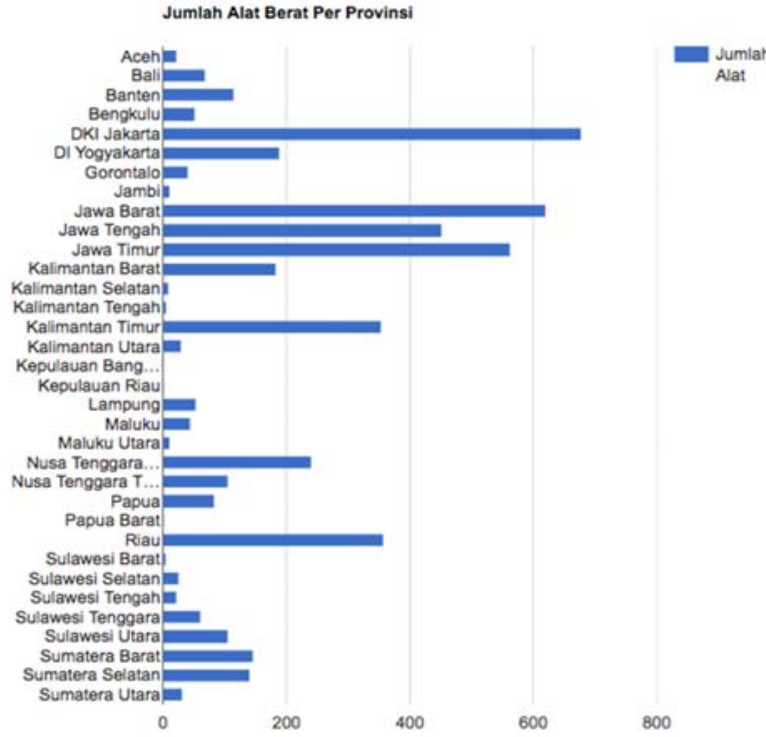

Fig. 2. Heavy Equipment Distribution by Province in Indonesia. (http://mpk.binakonstruksi.pu.go.id/summary/prov, downloaded on 20 Sept, 2017).

no special response unit with adequate skilled personnel to operate is available in the region. People on disaster sites are not always qualified to operate heavy equipment or conduct civil works. A lot of locals may want to help, but it can be dangerous for them because they have no or little experience and knowledge and skill to do the works properly. Therefore, it is essential to assess the construction skills of the local population and capacity of the local contractors.

\subsubsection{Availability of Liquid Fund during Post- Disaster Emergency Response}

According to the interviews, most of post-disaster emergency works including road clearing and emergency repair are hampered by the lack of availability of liquid fund on time. It is not rare for related agency, local PWD, to use their own source and budget in order that task can be done, despite the provision stipulated in the government No 22/2008 on reporting and accountability procedure. The Provincial Road Authority in West Java Province stated that most of road works fund for postdisaster emergency response utilised operational budget allocation to temporarily cover their works. However, there were issues of unreimbursed expenses when they tried to propose to BPBD to get reimbursement. In addition, it is a common situation on post-disaster emergency situation that fuel, equipment and operators cost much more than in the normal situation and will affect internal operational budget of the agency. Delayed or unapproved reimbursement usually will impact their internal budget for the current maintenance works and hamper the realization of their initial plan target.

\subsubsection{Restrictions in Procurement Schemes}

Under the local agencies, Bina Marga Provincial Government or Bina Marga Regency/City Government, contractors may be engaged to do road post-disaster clearing work. The Presidential Regulation No 70/2012 on Procurement of Goods and Services for Government stipulates a scheme for direct appointment for emergency post-disaster works, but government agencies are not allowed to do so if there is no declaration of disaster by the head of the local (or national) authority. However, during a post-disaster emergency situation, where timely response is really needed, selecting and appointing a contractor to do emergency works may take some time to process, initiated by inviting recommended (by local contractor associations) contractors, assessing their capacity (financial, skill and availability of equipment), negotiating the contract and then appointing the selected contractor.

\subsection{Multi Stakeholder Forum Group Discussion}

A Forum Group Disccussion where representatives from BPBDs, PWDs and Contractor Association from different cities/regencies in West Java has been conducted in November 2017 in order to get a better understanding of stakeholders' view related to contractor involvement in emergency response,

It was agreed during the discussion that participation of local contractors / private sector sides in disaster emergency response operations was an implementable and useful solution. However there were areas that need to be considered and elaborated more in detail, such as preparation, technical implementation, cost, coordination, and in particular supporting regulations.

Other factors to be considered when involving contractors in emergency response that were agreed during the discussion include :

1. Response time:

- Response time is the main variable, prioritize speed and readiness in solving the problem

- Good coordination

- Placement of facilities and resources in the proximity of disaster prone areas.

- Consideration of existing rules and regulation.

- Equipment types and distance to impacted areas

- Priority based on the level of importance of the service to be recovered, for example to prioritize between national roads or local roads

2. Approach to implementation:

- Improvement / revision of existing regulations related to disaster management and preparation of relevant SOP/guidelines for good emergency response to avoid obstacles during the implementation process.

- Prepare good MoU with the contractor association

- Local political will to involve the private sector in disaster management (disaster response)

- Involvement of local legislators, community, local government leaders before contractor involvement 
- Commitment from all parties involved in disaster management, including local leaders, for humanitarian purpose.

- Ensure budget allocation for disaster management supported by legal rule.

\section{Discussion}

\subsection{Improving The Contractor Association Role}

Participation of contractor association is needed to improve the preparedness and readiness of contractors, in order that the contractor can be safely involved in the emergency response with less common obstacles such as regulation restriction, uncertainty of estimated basic price for activities, and avoiding non trustable contractor in the field.

Cahill in [7] argues that taking the time to formulate a detailed management plan before a disaster strikes helps to identify and resolve potential issues that might arise ahead of time, without the pressure and time constraints that would be faced in the immediate aftermath of a disaster. Furthermore, if a disaster does occur, having a careful plan to follow minimizes response times and maximizes recovery efforts. Considering this perspective, contractor association can be involved in the preparation of the emergency response management plan before disaster strikes, and by assisting and preparing the contractor to be ready when disaster strikes in certain area.

Bellow are some recommended roles for contractor association to enhance contractor involvement during post disaster emergency response:

- Assists selected contractors to get earthwork specialty. This may help contractors to get required certification, which will justify his/her direct appointment for clearing works.

- Recommends selected contractors to obtain special emergency response construction permit based on their qualification and classification, which will help MoPWH in ensuring qualified contractors mobilized for post disaster emergency operation.

- Mapping and recommending the selected contractors to be based within a specific disaster prone area to enhance the effectiveness and immediate response during disaster emergency situation.

- Building capacity of the contractors to cope with disaster emergency situation so that sufficient resources can be ready.

- Requesting an amendment of Presidential Regulation No.70/2012 Concerning Procurement of Goods and Services for Government that will enable contractors to be selected before disaster happens in order to permit them to be mobilized by direct appointment once there is a disaster..

- Assessing contractor works after emergency situation for next recommendation.

\subsection{Improving Regulation}

As mentioned in [6], Kyoutei or agreement between local government and local contractor in Japan is effective and useful to speed up the response during disaster emergency situation. Unfortunately, in the current situation, the scenario like Kyoutei can not be implemented in Indonesia, as it is unsuitable in Indonesia according to the Presidential Regulation No.70/2012. Indonesian government agencies are not allowed to procure contractor services if the payment item is not clear and still uncertain. The scope of works of the contractor, the coordination line, the quantity of works, location of works and amount of contract need to be ensured before a contract is signed. Without clear definition of the items, road clearing and emergency works during disaster emergency can raise the issue of improper conduct of the responsible officer and can be considered as conducting corruption crime.

In practice, the available procurement scheme for post disaster response by direct appointment of contractors by the local agencies is still felt as far from effective and timely, in particular when the local agencies are also affected by the disaster and need to evacuate, while at the same time they have also the responsibility to conduct the evacuation of the survivors.

Another issue to consider also is the trust between government agency and the contractors, as in the eye of many government officers, contractors are not trustable and their participation in the emergency response is just for profit only, so they will maximize the profit during the uncertain emergency situation. This view was observed during the interview with local agencies, whereas many government officers felt the best way to respond to a disaster is by force-account or self-managed work, as they can not trust the contractor to provide satisfactory work, and in some cases even enter into dispute. Nevertheless, it is thought that under the responsibility of trustable contractor, emergency operation works can be implemented in a timely manner, without to much hassle from bureaucratic administrative procedure, at the same time as the local government agencies are occupied with the priority of saving people's life.

The procurement scheme for direct appointment is valid only for work under Rp. 200 million (approx..USD 150.000), low risk with simple work method/technology, and can be awarded only to small business entity, and the scheme can only be implemented when a disaster has been declared. According to our interview, usually post-disaster emergency status is only declared for a week and the longest time to respond is two weeks. In this case there will not be enough time for local agency to make the direct appointment process while responding to other activities of the post-disaster emergency. For them, it is easier and sometime faster if they respond by their own resources without any third party, provided that they have the require resources to do so.

To improve construction industry participation in post-disaster emergency response, there is a need to improve the regulations. The basic principle to apply is 
that it would be better to be prepared before the disaster happens, and contractor participation should be well arranged before disaster strikes. First, the Road Agency should conduct the process of contractor selection for future emergency response. Ideally, in one disaster prone area there would be one contractor selected to respond in post-disaster emergency but in case no sufficient budget allocation for that, one contractor can be assigned for one district. The criteria for selected contractor among others include the availability of qualified personnel and heavy equipment with experienced operators, good financial situation, high integrity, trustable in all services, recommendation from construction association, and have a good attitude for humanitarian operation..

Regarding the supply of construction materials, which experience shows that in post disaster situation, they are typically subject to high inflation, and the quality deteriorates as production processes becomes overstretched in order to meet the large scale demand [8], consideration should also be given to accommodate the fluctuation during the process. It is desirable that a robust post-disaster reconstruction planning is conducted prior to the occurrence of disaster. Systematic mapping of resource availability should be made available to the disaster prone areas to provide for effective emergency road repair. Over the emergency response and recovery period, to reduce potential resource cost fluctuations and their impacts on recovery, systematic mapping and monitoring of various construction resources should be conducted [10]. The use of E-catalogue will be useful for this process, but as construction costs are often fluctuating in post-disaster situation, a separation between normal situation E-catalogue and crisis or postdisaster situation E-catalogue need to be exercised.

\subsection{Standard Operational Procedure (SOP)}

Based on the FGD result, there are four main stakeholders which are to be involved in the emergency response preparation, namely BPBDs, PWDs, contractor association and the contractors. It is understood that the emergency works will be implemented in the emergency response stage, however the procurement process has to be completed during the preparedness stage.

If the Presidential Regulation No.70/2012 has been amended, BPBD may initiate the procurement process and coordinate with PWD who will conduct all the procurement process. PWD will have to determine the scope of works, price policy (e-catalogue) and contractor criteria/contractor qualification. The works can be confined to non-permanent works such as road clearing or temporary road access works. Unit price contract may be suitable for this kind of situation, because the total amount of the contract could not be determined in the beginning.

For emergency stage, contractor should mobilize their resources (personnel and heavy equipment) under
24 hours after disaster strikes as the policy is to reopen the damaged road within 24 hours. At this stage, communication become the key to the success of the operation and BPBD and PWD need to monitor the contractor works to mitigate new risk of another landslide during the evacuation or construction process.

In the transition stage, contractor together with the PWD Officers have to measure and verify the works that have been done. Later, approved request for payment based on the join measurement will be delivered to BPBD for the reimbursement process by using emergency fund or BTT. Fig.3 shows a scheme depicting the SOP for the implementation of the mechanism by all the involved parties during preparedness and emergency response stages.

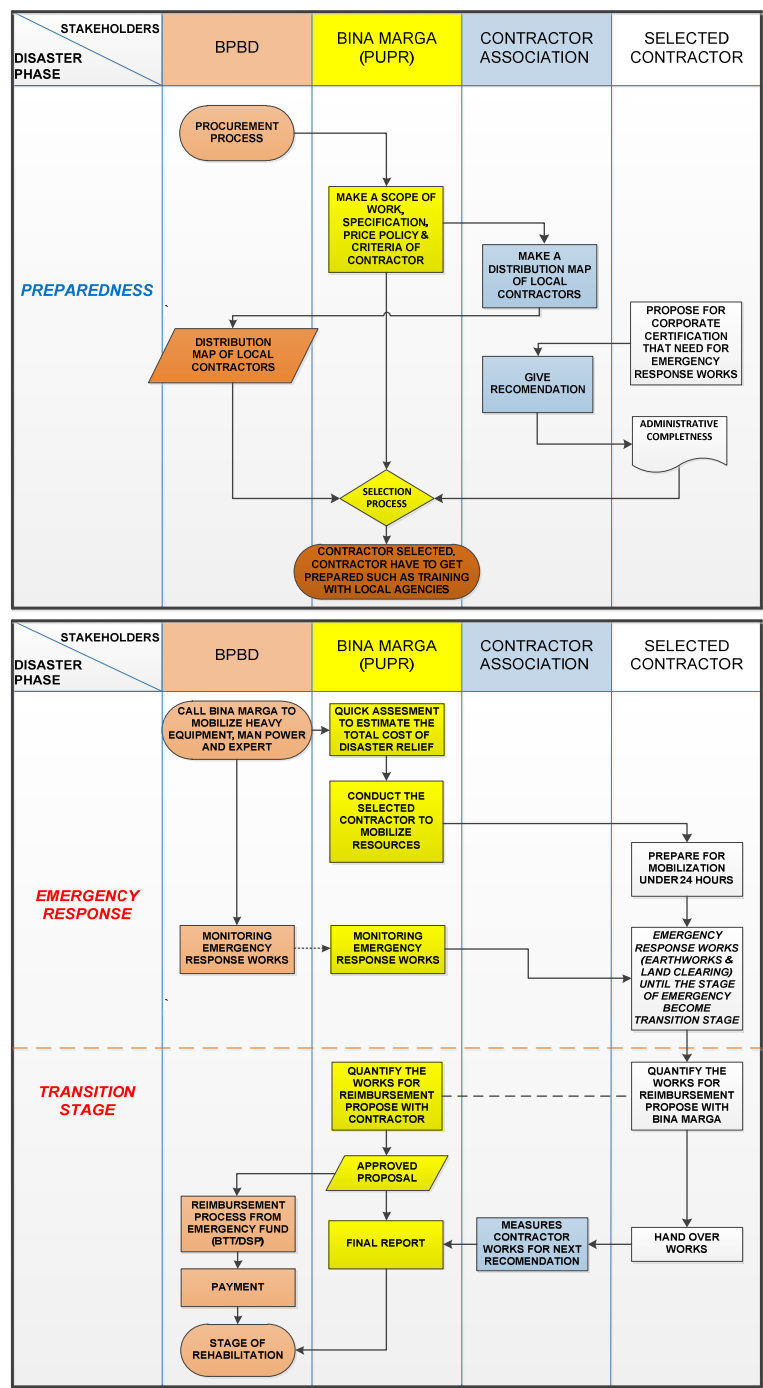

Fig. 3. Standard Operational Procedure for Preparedness, Emergency Response and Transition Stages 


\section{Conclusions}

Findings revealed some problems that occurred during post-disaster emergency response include lack of heavy equipment, lack of skilled human resource, the availability of emergency fund and tight policy of procurement scheme. Those barriers can be overcome by improving contractor roles for road clearing and emergency/temporary repair works during post disaster emergency situation.

The survey also concluded that Local Disaster Management Agency (BPBD) as a substantial stakeholder in the disaster emergency response does not give any objection for contractor involvement as long as it is conducted under the guidance of related department (Road Agency or PWD or MoPWH) despite the possibility of several obstacles, particularly regarding the current regulations.

In conclusion, some suggestions for improving the role of construction industry are proposed:

1. To improve contractor association involvement in role sharing among local contractors for more effective post-disaster emergency response.

2. To amend regulation the current government regulation on Procurement of Goods and Services for Government. The amendment should involves changes that allow procurement process to be initiated before the occurrence of disaster in order to promote disaster mitigation measure, as it is believed that preparation during normal time will produce better result rather than arrangement during postdisaster crisis. Both direct appointment and tender schemes with unit price based contract are to be implemented before the disaster.

3. Road Agency or PWD should maintain an eCatalogue special for post-disaster emergency response purposes to facilitate the procurement process and control the fluctuation of price due to scarcity of resources.

The authors wish to extend their gratitude and appreciation to the Institute of Research and Community Outreach of ITB who provided the grant for this research under the P3MI Program.

\section{References}

1. F Grünewald, A Binder, Y Georges, Inter Agency Real Time Evaluation in Haiti. Final Report. Global Public Policy Institute, 2010

2. E. Hayat, RDG. Amaratunga, Road reconstruction in post - disaster recovery; the challenges and obstacles (University of Salford Manchester, 2011) http://usir.salford.ac.uk/23372/1/23372.pdf

3. P Stringfellow, Construction contractors involvement in disaster management planning, Australasian Journal of Constr. Econ. \& Build., 14 (2) 120-132 (2014)
4. ASEAN Disaster Management Reference Handbook , CFE-DMHA, 2015

5. M.B.F. Bisri, Choose Your Partner Correctly in Emergency Response: Partnership Innovation Learned from the Great East Japan Earthquake and Tsunami 2011 - Final Report, UNOCHA 2013 Humanitarian Research and Innovation Grant Program, New York (2014).

6. M. Onishi, K.S. Pribadi, The Role of Construction Industry in Post Disaster Recovery (Proc.of 3rd International Conference on Earthquake Engineering and Disaster Mitigation - ICEEDM, Bali, 2016)

7. K. Cahill, - Proper Debris Management - Key to Disaster Recovery and FEMA Assistance, Disaster Recovery Today 13 (Adjusters International Inc. New York, 2011)

8. https://www.gatra.com/nusantara/jawa/287430bencana-tanah-longsor-landa-4-desa-di-kabupatenbanyumas

9. J de Silva, Lessons from Aceh - Key Considerations in Post-Disaster Reconstruction, Practical Action Publ., 2010

10. Y. Chang, S. Wilkinson, E. Seville, R. Potangaroa, Changes in resource need for post-disaster reconstruction: a longitudinal study in China (Journal of Build. Res.\& Inf.40(3) 327-336 (2012) 